Recommended citation: Østergaard-Nielsen, Eva and Ciornei, Irina, ‘Political Parties and the Transnational Mobilisation of the Emigrant Vote', forthcoming, West European Politics

\title{
Political Parties and the Transnational Mobilisation of the Emigrant
}

\author{
Vote \\ Eva Østergaard-Nielsen \\ Department of Political Science, UAB \\ Campus UAB, 08193 Bellaterra, Spain \\ Eva.ostergaard@uab.cat \\ Corresponding author
}

and

Irina Ciornei

Institute of Sociology,

University of Bern

Fabrikstrasse 8, CH-3012 Bern

irina.ciornei@soz.unibe.ch

Acknowledgements: The authors thank the participants and discussants at the Europeanist Conference, ECPR and conferences and seminars at Sussex University, the Autonomous University of Barcelona, and the University of Louvain for valuable feedback on earlier versions of this paper. We also thank the anonymous referees for helpful comments and suggestions. This work was supported by the Spanish Ministry of Economy and Competitiveness, grant number CSO2010-16353. 


\begin{abstract}
:
The relationship between political parties and voters is usually analysed in a national framework. However, the majority of states worldwide allow their emigrant citizens to vote from afar. This paper analyses how parties confront the challenge of mobilising voters across borders. We present an analytical framework for comparing the scope of party transnational mobilisation strategies across different electoral systems. Drawing on a contextualised qualitative analysis, the paper analyses transnational electoral mobilisation of the emigrant vote in recent elections in Spain, France, Italy and Romania. The analysis shows that a cost-benefit analysis of electoral incentives explains the scope of transnational campaign efforts of many of the political parties, Yet, we also suggest locating the analysis of party strategies in the particular context of the transnational electoral field, including the high dispersion, uncertainty and volatility of the emigrant vote and the overlap between the electoral arenas among emigrants and at home.
\end{abstract}

Keywords: Parties, transnational, emigrants, elections, campaigns. 


\section{Introduction}

The linkages between parties and citizens are usually analysed in a framework which assumes that all voters reside within the national boundaries of the state. However, the majority of states worldwide, including 23 EU member-states, allow their citizens residing abroad to vote in the elections of their countries of origin. ${ }^{1}$ The implementation of external voting rights leads to the formation of new transnational political spaces of electoral and party competition. The analysis of campaign strategies, broadly understood as the actions undertaken by parties to influence voter decision, have been argued to constitute an important first step in understanding the structuring of electoral spaces (Karp et al. 2007; Lago and Martínez 2007). It is therefore timely to explore the role of parties in crossborder democratic processes of mobilisation of the emigrant vote. How do parties confront the challenge of the transnationalisation of the electorate during electoral campaigns?

This question addresses concerns across several fields of study. While marginal in the literature on parties and elections, the issue of how policies of emigrant voting rights decouple citizenship and territoriality stands increasingly central in studies of transnational migration and outreach policies of sending states. A growing number of scholars have unpacked the transnational outreach policies of emigrant countries and highlighted that political parties make their presence felt among enfranchised emigrant collectives (Burgess 2018; Meseguer and Burgess 2014; Paarlberg 2017; Tintori 2012; Østergaard-Nielsen 2003). In these studies, it is also evident that not all parties reach out to emigrant voters in equal measure. In order to better understand what motivates or constrains parties, there is a need for more comparative analysis of variance across parties and countries. At the same time, this allows us to examine to what extent some of the concepts, measures, and hypotheses used to explain party behaviour on the national electoral scene may also explain parties’ engagement with transnational electorates.

An important point of departure is the difference in motivation and limitations for party outreach to external/emigrant and domestic electorates. In terms of motivation we argue that the electoral impact of the emigrant vote depends on a range of factors such as the size and turnout of the emigrant electorate, the electoral system and the closeness of the election in the homeland. Although there is no systematic study of this effect, there are examples of the emigrant vote having a decisive impact on homeland elections such as the case of Italian legislative elections in 2006 or the Romanian presidential elections in 2007. 
Limitations include that the political preferences of emigrant voters are un-polled in between elections, they are dispersed across often large numbers of countries of residence and therefore much more difficult to anticipate and mobilise compared to home constituencies (Caramani and Grotz 2015). Consequently, examining the motives, constraints and opportunities for why parties reach out to emigrant voters provides a welcome opportunity to strengthen the dialogue between studies of the politics of transnational migration, outreach policies of sending states, and the broader field of party and electoral studies.

We compare the transnational campaigns for the emigrant vote across the main parties of Spain, France, Italy and Romania. These countries are similar in that they all have external voting rights and relatively large numbers of external voters residing abroad. However, they differ in terms of the particular emigrant electoral system, the past electoral impact of the emigrant vote as well as the trajectory of emigration (long-standing/recent). There are two overall types of electoral systems for emigrant voters. In most electoral systems, the emigrant vote is counted in the district in the homeland where the emigrant or her parents were last registered. A small albeit recently growing number of electoral systems allow emigrants to elect their own candidates and count the emigrant vote in a determined number of emigrant voter districts.

In the following sections we present a framework for analysis of different degrees of transnational mobilisation of political parties. We then discuss how different configurations of macro and meso level factors may influence party strategies in the transnational electoral field across the four cases. The empirical analysis includes a mapping of the scope of transnational party strategies and a qualitative contextualised analysis of the main trends in and motivations for transnational campaigns among a selection of the parties. As detailed below, both sets of analysis draw on documentary material from the parties as well as interviews with campaign managers or other party representatives engaged in mobilising emigrant voters.

\section{Defining Transnational Electoral Outreach}

A wealth of studies have highlighted how the mobilisation and electioneering strategies of political parties adapt to the dynamics of changing and more volatile voter-party 
alignments. Among the general trends is that parties have a more centralised and professionalised party organisation in constant campaign mode (Dalton et al. 2011; Mair et al. 2004). Parties have shifted towards more 'Americanised' campaigns relying on media impact, use of the internet of social media, opinion polls, and more personalised campaign messages (Dalton et al. 2011; Gibson and Rommele 2009; Norris 2005). The transnational mobilisation of the emigrant vote needs to be located in these changing contexts as well as the particular characteristics of the transnational electoral field.

In systems without special emigrant representation, the campaign strategies can be measured in terms of the amount of resources parties dedicate to be visible abroad among emigrant voters. In systems with special emigrant representation, the party decides whether to present candidates in the emigrant voter districts and how much support to offer them. In order to compare transnational campaign strategies across different electoral systems we suggest a framework which focuses on two dimensions: a) the formulation and communication of a particular set of policy proposals directed at emigrants, that is, the attempt to establish an ideological linkage (Dalton et al. 2011) with emigrant voters. b) The establishment of a transnational infrastructure of local branches of emigrant party members or supporters. These dimensions are not exhaustive. Other dimensions, notably the use of the internet and social media and alliances with parties, emigrant associations and other organisations in countries of residence would serve to complete the understanding of transnational electoral campaigning. Moreover, the intensity of local campaign activities, including visits of leaders of each party, or the particular effort of candidates for seats reserved for emigrants defines party outreach efforts. Even so, we opt for these broader indicators of party outreach in order to gather consistent information across both countries of origin and the many countries of residence as well as across systems where emigrants elect their own representatives and systems where the vote is part of the general pool at home.

In terms of ideological linkage, we refer to the extent to which parties seek to engage with emigrants as an electoral group with a particular set of concerns. Strictly speaking the enfranchisement of the external electorate, in particular in a time of growing online access to homeland political affairs, could simply mean that emigrants would orient themselves in the general national campaign material and vote for the candidate or party that best correspond to their political preferences in the country of origin. However, emigrants may also have a particular set of problems and needs in relation to their 
homeland. Indeed, the growing literature on outreach policies by sending states has highlighted how countries of origin seek to support the socio/economic, political and religious situation and rights of their citizens abroad and institutionalise their continued political and economic relations with their country of origin (Østergaard-Nielsen 2016; Gamlen 2008; Collyer 2013; Ragazzi 2014). Across the countries we have studied, the list of issues of concern to emigrants largely reflects these dimensions. Campaign material address the rights and obligations of non-resident citizens and include extension or restriction of their political rights (emigrant voting arrangements), social rights (access to social security and other welfare provisions in the homeland; homeland support of language and schooling of emigrant children), consular services, return policies, and tax arrangement for non-resident citizens abroad. Also, the party may include broader messages of concern and recognition of emigrants in their main electoral programmes. The salience of these issues in party programmes is an indicator of party interest in emigrants as a voter group.

In terms of transnational infrastructure we focus on the network of external local party branches which represent the political party among the emigrant collectives in their respective countries of residence. One could suppose that transnational campaigning should be easier in the age of digital communication. It is no more difficult to log on to the French Socialist Party (PS) Facebook page from New York than from Paris. Similarly, national mass media is often globally available for anyone with an Internet connection and the right language skills. However, evidence from broader studies of party linkages suggests that local campaign events are a priority and direct contact with a candidate or party worker has been identified as the potentially most influential campaign activity (Dalton et al. 2011; Karp et al. 2007). It is therefore interesting to scrutinise to what extent political parties extend this logic to the external electorate in terms of committing resources to on-the-ground campaigning abroad.

Together these two dimensions combine to the following categories of degrees of transnational party strategies: 
Table 1: Four categories of transnational party strategies.

\begin{tabular}{|c|c|c|c|}
\hline & \multicolumn{3}{|c|}{ Degree of ideological linkage } \\
\hline \multirow{2}{*}{ 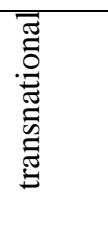 } & & Low & High \\
\hline & High & $\begin{array}{l}\text { Parties with few policy proposals } \\
\text { related to emigrants but an extensive } \\
\text { transnational infrastructure }\end{array}$ & $\begin{array}{l}\text { Parties with many policy proposals related } \\
\text { to emigrants and an extensive transnational } \\
\text { infrastructure }\end{array}$ \\
\hline 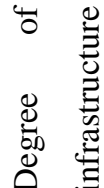 & Low & $\begin{array}{l}\text { Parties with few policy proposals } \\
\text { related to emigrants and a limited } \\
\text { transnational infrastructure }\end{array}$ & $\begin{array}{l}\text { Parties with many policy proposals related } \\
\text { to emigrants but a limited transnational } \\
\text { infrastructure }\end{array}$ \\
\hline
\end{tabular}

\section{Motives and Constraints for Transnational Outreach to Emigrant Voters}

\section{Costs, Benefits and Electoral Institutions}

Theories of party competition argue that parties contest elections and strengthen their campaign efforts when the benefits outweigh the cost. This type of analysis centres on the extent to which party resources interact with electoral institutions, political competition and party expectations regarding electoral behaviour. In terms of the relationship between electoral systems and the entry decisions of party elites, the traditional understanding is that majoritarian SMD systems tend to favour two-party systems and proportional systems tend to favour multi-party systems through both a mechanical and a psychological logic (Duverger 1954; Cox 1997). Moreover, parties are more likely to strengthen their campaigns in candidate-based and single-member districts where they expect the votes to turn into seats (Cox 1999; Karp et al. 2007).

In the majority of electoral systems, the emigrant votes join the general pool of votes in the last district of residence. Hence, winning the emigrant vote does not necessarily guarantee any seats and the impact of emigrant voters depends on the general electoral rules in place. In that sense the number of parties campaigning abroad could be more or less an extension of the situation on the national electoral scene. In more proportional systems, such as Spain, the emigrant vote can boost the overall national vote share of any competing party, in more majoritarian systems, such as the UK, only the votes for the winning party in that particular district count. To some extent the system of special emigrant representatives is akin to a candidate based single majority pluralist system where the winner takes all in each district. This would favour a two party system in the emigrant districts regardless of the party system prevailing in the country of origin. 
Political competition includes another set of factors explaining the intensity of electoral campaigns. Across electoral systems, parties have an incentive to strengthen their campaign activities if the electoral result is expected to be close (Karp et al. 2007; Kriesi et al. 2005; Matsusaka 1993). Similarly, parties could be expected to intensify their chase for the emigrant vote if the electoral result among emigrants is expected to be close (in cases of special emigrant representatives) or in their homeland district (in cases of emigrant votes being part of the pool in the homeland). In either case these incentives are further reinforced in cases where the overall national result is close and a few seats can tip the balance between the main parties or coalitions. A recent study shows that MPs pay more attention to emigration issues in their legislative and non-legislative activities the more their party receives the emigrant vote and when previous electoral result among emigrants was close (Østergaard-Nielsen and Ciornei 2017).

The electoral incentives and patterns of representation deriving from the different configurations of electoral systems and competition have been found to be moderated by different level of resources among political parties (Karp et al. 2007). Larger parties with more resources and expertise tend to have a wider appeal related to their more comprehensive policy platform and the fact that they are serious contenders for political office than do single issue parties at the extremes of the electoral spectrum (Dalton et al, 2011). Notably, parties with mass organisations, which are usually a feature of mainstream centre-left and centre-right parties, have been found to be more capable of bridging the distance to not just partisan but also independent voters (Rohrschneider and Whitefield 2012). Larger party organisations include developed party structures which enable the party leadership to communicate with local chapters, linkages with interest groups and strong membership figures (Ibid). It is likely that parties with such broader appeal and more resourceful and well connected organisations and campaign machinery are also better equipped to take on electoral mobilisation abroad. Established parties which have a longer trajectory of mobilising emigrant voters, are also more likely to continue to do so since they already have the relevant infra-structure and connections in place. In contrast, new parties, especially those running for the first time, have less knowledge of their potential voter support abroad and could be expected to mainly prioritise the domestic electoral campaign over the extension of a transnational infra-structure to reach out to emigrants. However, a dimension particularly relevant to the transnational electoral setting is also the extent to which parties grow out of or are linked up with transnational social 
movements or interest groups facilitating a stronger international grassroots-based network of contacts. A point in case are the grassroots links of green parties (Dietz 2000) or protest parties which have a stronger transnational network of contacts even if they are newcomers on the electoral scene.

According to this type of cost-benefit analysis we would therefore expect that the category of the parties with an extensive transnational infrastructure and many emigrant related policies include mainly the larger more established parties with a record of substantial emigrant voter support as well as parties who grow out of social movements or maintain a strong affiliation with transnational networks of activists. There should be more incentive for transnational party campaigns in systems with special emigrant candidates and districts. Meanwhile the category of the parties with a limited transnational infrastructure and few proposals related to emigrants in their electoral programmes would include small and/or new parties with negligent prior emigrant electoral support. Elections where the emigrant support is expected to be close and make a difference in the overall results would reinforce the incentive to go transnational among parties in either category.

\section{Lack of Information and Overlapping Electoral Arenas}

Several main characteristics of external voting rights and transnational electoral fields may temper the straightforward application of a cost-benefit analysis to the transnational outreach of parties. First, information on emigrant electoral behaviour is relatively imperfect compared to the national scene. Parties face an external electorate dispersed in many different countries of residence, often relatively low turnout rates, and uncertainty regarding emigrant voter preferences, which, importantly, are un-polled in between elections. The emigrant vote does not necessarily follow the domestic vote as has been illustrated by the fact that Spanish emigrant voters have always supported the incumbent government since the granting of voting rights in 1978. Consequently, it is more difficult for parties to target those emigrant votes that could prove crucial to winning a seat in an external or national district. Instead, parties may seek to catch up with their main competitors in order to increase their visibility in terms of both their policy message and presence on the ground in order not to be relatively absent in the eye of the emigrant voter.

This dimension of uncertainty can moreover be further reinforced if the trajectory of emigration and/or the implementation of external voting rights are more recent. Parties 
in a country which implements external voting rights many decades after major waves of outmigration may have a somewhat clearer idea of the political profile of the emigrants. In contrast, those countries which implement external voting rights after only recent flows of outmigration may have less knowledge of the political preferences and organisation of their citizens abroad. We could therefore expect parties in these countries to be wearier of investing in a transnational campaign.

Second, studies of party behaviour in the domestic setting have highlighted that parties campaign in districts where they are unlikely to win because of the interdependence between different electoral settings (Best 2010; Guinjoan 2014; Raymond 2016). An interesting concept in that respect is that of overlapping electoral arenas, with electoral arena referring to any constituency or group of constituencies where elections are being held (Guinjoan 2014). The decision to enter into competition in one electoral arena can be 'contaminated' by the chances of achieving representation in another overlapping electoral arena. For instance, in Spain regional parties with little electoral support outside their own region, may still run nation-wide campaigns in national elections because such larger campaign boosts their image as a party with a national reach in the eye of the regional electorate (Lago and Montero 2009).

The concept of overlapping electoral arenas can also apply to party transnational outreach. First, campaigning abroad in national legislative elections may be closely related to domestic overlapping electoral arenas such as an upcoming presidential or regional election where the emigrant vote may be more influential for the outcome. Parties may seek to mobilise the emigrant vote in elections with no prior or expected record of closeness or particular impact of the emigrant vote because the vote has been or is expected to be important in other upcoming elections. Second, this concept can apply to the interdependence, which may exist between the emigrant and homeland electoral arenas. The transnational character of most contemporary migration blurs the distinction between domestic and external electorates and districts. Recent studies, in particular based on cases from central and Latin America, have argued that migrants can be part of political processes in their countries of origin through their transfer of remittances, values and political opinions (Boccagni et al. 2015; Mahmoud et al. 2013; Pfutze 2014). In continuation it could be expected that parties may be motivated to reach out to emigrant voters because they believe that their linkage with the emigrant electorate may indirectly spill over into support from the local electorate. In this scenario, overlapping electoral 
arenas between abroad and at home could explain why emigrants are of interest to smaller parties whose main national constituencies include high rates of voters abroad.

\section{Emigration, Voting Rights and Electoral Dynamics across the Cases}

The countries analysed here have large numbers of emigrants residing abroad, but they differ in terms of the history of emigration, geographical dispersion and overall profile of emigrants (see table 2). Spain and Italy have longstanding labour emigration, yet the current profile of citizens abroad is mixed as it includes several generations and recent outflows of highly educated migrants ( Lugilde 2007; Tintori 2012). The French expat community has a large proportion of highly skilled that even bypasses the rate in the country of origin. ${ }^{2}$ Romanian emigration intensified post 1989 with intense flows of labour emigration to other EU member-states and their profile was, at the time of the research, less known to the political parties.

Table 2. Main characteristics of the emigrant electorate in Spain, Italy, Romania and France.

\begin{tabular}{|c|c|c|c|}
\hline Country & $\begin{array}{l}\text { Number of citizens } \\
\text { abroad }\end{array}$ & $\begin{array}{l}\text { Number of voters } \\
\text { abroad/\% over total } \\
\text { electorate }\end{array}$ & $\begin{array}{l}\text { Main regions and countries of } \\
\text { destination }\end{array}$ \\
\hline Spain & 1702778 & $\begin{array}{l}1482786 / \\
4,1 \%\end{array}$ & $\begin{array}{l}\text { South America (Argentina), Europe } \\
\text { (France, Germany) }\end{array}$ \\
\hline Italy & 4341156 & $\begin{array}{l}3494687 / \\
7,5 \%\end{array}$ & $\begin{array}{l}\text { Europe (Germany, Switzerland), South } \\
\text { America (Argentina), North America, } \\
\text { Australia }\end{array}$ \\
\hline Romania & $3007350 *$ & n.a.* & Europe (Italy, Spain) North America \\
\hline France & 1611054 & $\begin{array}{l}1006700 / \\
2,3 \%\end{array}$ & $\begin{array}{llll}\text { Europe (Switzerland, UK), } & \text { North } \\
\text { America, Middle East (Israel), North } \\
\text { Africa (Morocco) }\end{array}$ \\
\hline
\end{tabular}

Own elaboration from: Ellis et al (2007); http://www.idea.int/vt/; France: Rapport du Gouvernement sur la situation des Français établis hors de France 2014; http://www.diplomatie.gouv.fr; http://www.interieur.gouv.fr/Elections/Les-resultats Italy: http://elezionistorico.interno.it/; AIRE, http://servizidemografici.interno.it; Romania: http:/www.becparlamentare2012.ro/: http://www.bec2009p.ro; United Nations, Department of Economic and Social Affairs (2013). Trends in International Migrant Stock: Migrants by Destination and Origin, Spain: Pere, http://www.ciudadaniaexterior.empleo.gob.es; http://www.infoelectoral.interior.es/min/. *Due to the lack of registration of Romanian voters abroad we only have the number first generation Romanians abroad. Numbers of emigrants, registered voters and turnout are from the last election before 2013. 
In terms of type and recent changes in voting rights, Spain has allowed emigrants to vote since the constitutional changes related to the transition to democracy in 1978. However, in the year before the elections in 2011 these voting rights were restricted through a change of registration procedure (el voto rogado) and a disenfranchisement at the local level. Although Italy has an emigration trajectory comparable to Spain, emigrants were not granted the right to vote until the electoral reform in 2001 on the initiative of the right wing National Alliance. This reform allowed Italians abroad to elect 12 deputies and six senators across four electoral districts abroad. Romania allowed for the external vote in 2001 with a stronger reference to the enfranchisement of the Romanian minority in

Hungary than the emigrant workers, the majority of whom had left over the past decade. An electoral reform in 2008 also gave the emigrants the right to elect four deputies and two senators across two electoral districts. French emigrants have been able to vote in presidential elections since 1981 and have an even more longstanding trajectory of indirectly elected special emigrant representatives in the Senate (currently 12 senators). An electoral reform led by the Union for a Popular Movement (UMP) in 2008 allowed the French expats to vote and elect 11 deputies in legislative elections for the National Assembly in 2012.

Consequently, Italy and Spain have largely similar histories and volumes of emigration but have different emigrant electoral systems. The inclusion of France allows us to compare party transnational outreach during the first legislative election with emigrant voting rights. Meanwhile, Romania is a case of more recent outmigration and relatively less information on the size, profile and preferences of the emigrant voters. Because of the recent electoral reforms in the cases of Romania and France, three of the four cases analysed in this paper allow emigrants to elect their own legislative representatives while one case, Spain, does not. Although such systems are a minority worldwide, several EU member-states (France, Romania, Italy, Portugal and Croatia) have opted for them during recent electoral reforms.

Moreover, the electoral dynamics of the external vote vary across the cases studied. Turnout is usually low among emigrant votes as the cost of voting (e.g. logistics, access to information) is much higher than for voters at home (Lafleur 2013). Across the cases, Spain, Italy and France have experienced fairly stable turnouts between 30 and 40 per cent (calculated as number of voters over number of registered voters), although the turnout for Spain dropped all the way to five per cent in 2011 after the registration restrictions. 
Turnout for Romania is difficult to assess as there are no official statistics for the number of voters abroad and no system of voter registration. Romanian emigrants vote by simply showing their passport at the polling station. An estimate based on UN foreign born Romanian residents abroad indicate a very low turnout of around 2 per cent in legislative elections and 4 per cent in presidential elections.

The electoral preferences among emigrant voters are not always aligned with the voting patterns in the domestic constituencies, nor are they consistent over time. For instance, Spanish external voters tend to vote for the incumbent party (Lugilde 2007) although the electoral support for the two main parties of the Popular Party (PP) and the Spanish Socialist and Workers Party (PSOE) was very close in the 2011 election. In the case of France, the presidential candidate for the UMP (and its predecessors) has always won the emigrant vote (Collard 2013). In Italy, the introduction of the right for emigrants to vote and elect their own representatives was originally supported by the right wing National Alliance, yet it is the centre-left which has taken more support among overseas voters since 2006 (Tintori 2012).

Also, the impact of the vote differs across the cases. In Italy and Romania there are examples of the emigrant vote changing the overall outcome of the election. The close call of the Italian 2006 election heightened the role of the overseas vote when the emigrant candidates for the Senate secured the majority for the Prodi led coalition, despite the centre right gaining more votes. In both 2006 and 2008 competition in some of the districts was very close with less than one per cent difference between the main parties. Moreover, the competition in the emigrant districts was close not only between the two main parties of the Democratic Party (PD) and the People of Freedom (PdL), but also between smaller parties such as the centrist Union of the Centre (UDC) the Italy of Values party and emigrant led parties such as the Associative Movement of Italians Abroad (Maie). In particular in the case of the Senate elections, the results changed markedly across the districts between 2006 and 2008 showing the parties that these are not safe seats. In the case of Romania, the emigrant vote gained importance in the presidential elections during the 2000s. Most notably the Democratic Liberal Party (PDL), led by Basescu, won the presidential election in 2009 thanks to the emigrant vote. The emigrant vote was not decisive in the 2008 legislative election, but the PDL won the seats in all districts for both the National Assembly and the senate except for the $4^{\text {th }}$ world district. ${ }^{3}$ 
In the case of Spain and France the vote has never made a difference to the overall outcome of national legislative (Spain) or presidential (France) elections. However, the debates of the UMP proposal for special emigrant representatives in the National Assembly indicate that parties do care about the emigrant vote. These debates included accusations of gerrymandering favouring the UMP from the Socialist Party (ØstergaardNielsen et al. 2015). In the case of Spain where the vote is counted as part of the pool of votes in districts in Spain, the emigrant vote has been decisive for the electoral outcome in close races at the district level. In 2008, the emigrant vote guaranteed a seat for the Popular Party over the Convergence and Union (CiU) in Catalunya and in the Canary Islands it secured a seat for the Canarian Coalition (CC) in the Senate. ${ }^{4}$ Moreover, the impact of the emigrant vote has proven to be decisive for the overall allocation of seats in close races between parties in elections in the autonomous communities with a high percentage of emigrant voters such as Galicia, Asturias, the Basque Country or the Canary Islands. ${ }^{5}$ In a few cases the emigrant vote decided the composition of the regional government such as in Galicia 2005 and Asturias 2012. ${ }^{6}$

\section{Methodology}

In the following analysis we centre on a broad selection of parties with parliamentary representation across the largely moderate and bipolarised party systems in all four cases (See Appendix 1). The research focuses on the most recent election in each country during the period of research from 2011-2013. The data is collected through 51 interviews with representatives from central or local offices and emigrant representatives from 25 political parties, online documentary research on national press, party websites, bulletins and party Facebook pages for citizens abroad, analysis of main emigrant online news forums and official statistical information on external voters and voting. The interviewees have been chosen through general contact with the party. Some parties, like the Italian Democratic Party or the main centre-right and left parties in Spain, have a coordinator of the transnational infrastructure and electoral outreach to emigrants. In most cases the parties have referred us to the general campaign coordinator or one of the special emigrant representatives with a coordinating role in transnational campaigns. We have triangulated information from research on party documents with the information and interpretation from interviews. 
We first present an overview of the distribution of the parties across the four categories of transnational party strategies combining ideological linkage and transnational infrastructure. Here the ideological linkage is counted as the word-ratio related to emigrants in the electoral programme, of each party akin to the identification of section length as a measure of salience of a particular policy domain (Pappi and Seher 2009). The relevant sections, identified through the search for a pre-established list of keywords, are in some cases titled sections or phrases within the general programme and in a few cases specific emigrant programmes posted on the website of the party. The choice of identifying a word-ratio instead of a ratio of quasi-sentences is related to our interest in identifying not just the number of statements or policy proposals (see Appendix 1), but also the broader formulations regarding the role and importance of emigrants.

The numbers of local branches in countries of emigrant residence are based on the self-reported numbers of the political parties through their own documentary sources (websites) and/or through interviews. We have tended to prioritise the information collected through the websites when establishing the number of branches, while the interviews served to deepen our understanding of the development of branches abroad. In a few cases (four) we only have the estimate by the party representative obtained through the interview (see furthers details in Appendix 1). The interviews have clarified that across the cases, the actual nature of these local branches range from staffed offices to a list of contact persons per country of residence of the website of the party. Given the high dispersion of values of policy proposals and transnational infrastructure, the placement of parties according to the categories mentioned in Table 1 is based on the log value of ideological linkage and branches (see Figure 1).

\section{Going after the Emigrant Vote}

The initial mapping of the degree to which parties go after the emigrant vote shows both differences and similarities among parties across the cases. In the category of parties with an extensive transnational infrastructure and many policy proposals related to emigrants, we find all the major and established centre-right and centre-left parties in the four cases. In line with the Duvergerian scenario, these parties have a history of taking the lion's share of the emigrant electoral support and have, given their trajectory and size, more resources to meet the cost of transnational campaigning (see Appendix 1). 
Figure 1: Transnationalisation of electoral campaigns among parties in Spain, Italy, France and Romania

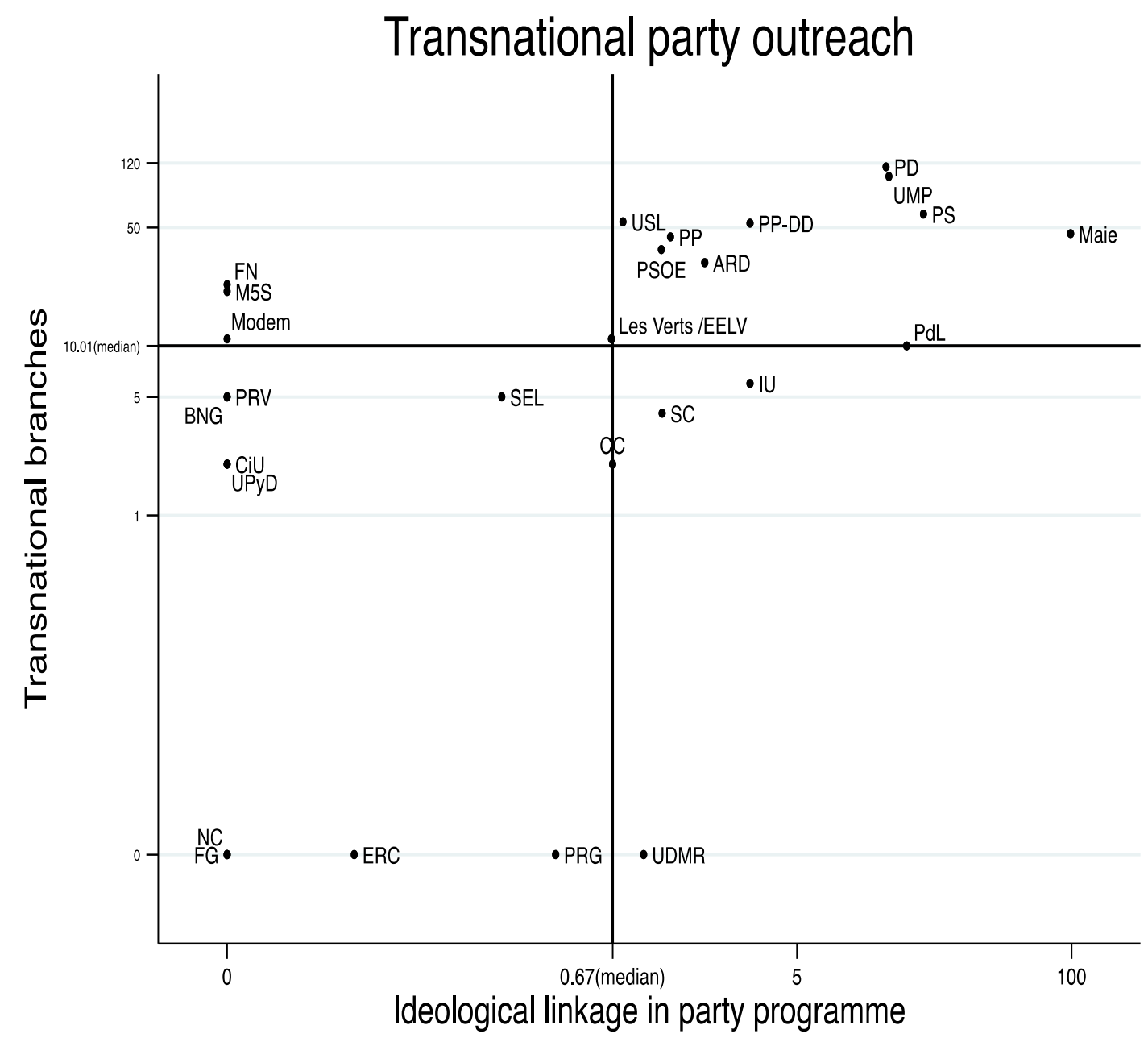

Notes: Logarithmic scale. Axes cross at the median values of the variables ideological linkage (0.67) and transnational infrastructure (10.01)

Sources: For sources and abbreviations, see Table 2 and Appendix 1.

Across the cases these parties also have a set of more context specific electoral incentives to care about the emigrants and the emigrant vote. In the case of Spain, both major parties make reference to the regional electoral dynamics as an incentive to reinforce their external campaign structure and message in national elections. First, the PSOE expanded its transnational network and policy message towards emigrants during 19962003 under the leadership a leading PSOE figure of Galician descent (Interview PSOE, January 2012). Later the PP intensified its transnational network from a presence in only six countries to 44 offices in 27 countries between 2008 and 2011 (Interview PP, December 2011) following the PPs loss of its long-standing government of Galicia to a 
coalition between PSOE and the Galician Nationalist Bloc (BNG) in 2005. During this period the electoral programmes of both parties aimed at emigrants also tended to catch up with each other as the parties addressed more recent emigration and a more complex profile of the emigrant voter to encompass a broader range of interests. The restriction of voter registration in 2010 did not lead the PSOE or PP to diminish the scope of their campaign messages to emigrants or their numbers of local branches abroad, despite expectations of a lower turnout.

Italy has a shorter trajectory of emigrant voting than Spain, but the decisive role of the emigrant vote in the 2006 elections has been an incentive to pursue the emigrant vote. Moreover, there have been close runs in several emigrant districts and in particular in the two American districts where Italian parties compete with emigrant led parties such as the Maie. Although the enfranchisement of emigrants was largely driven by the right, the centre-left PD has set up a very comprehensive network of local branches (circuli). These branches are embedded in a multi-level structure of regional and national coordinators similar to the organisation of the PD within Italy (interview with PD, June 2013). In contrast the transnational network of the centre-right PdL is not just more limited in terms of numbers but also appears less institutionalised. The PdL itself links this to the fluid person-based management of the PdL (Interview PdL, June 2013).

In France, parties cite the introduction of special emigrant representatives in the National Assembly after 2008 as an important incentive to intensify their campaign for the emigrant vote in the 2012 legislative election. Both of the main parties have a longstanding connection with emigrant voters due to their indirectly elected special representatives in the Senate and their voting rights in presidential elections from 1981. In 1980 sympathizers of the PS set up the Democratic Association for the French Abroad (ADFE) as a balance to the right-wing dominated Union for the French abroad (UFE) created already in 1927 (Collard, 2013). In terms of party organization abroad, the Rally for the Republic (RPR), precursor to the UMP, set up their own federation for the French abroad in the late 1970s, followed by the PS (1983) and the Union for French Democracy (UDF) (1984) (Interviews with PS and UMP, November 2012). With the UMP-led electoral reform in 2008 both major parties have intensified their transnational campaigns. Both parties launched comprehensive electoral programmes only for emigrants, with the PS programme in particular including 28 detailed sections. 
In the case of Romania, the decisive role of the emigrant vote in the 2009 presidential elections combined with the introduction of special emigrant representatives encouraged all major Romanian parties to establish networks of local branches and contact points in especially Europe and the USA. Similar to the 'catch up' logic in the other cases, one of the major parties went transnational before the others. While the other main parties had mainly ignored the emigrant vote, the PDL had since 2006 established a wide network of branches in especially Spain and Italy from 2006. In the run up to the 2008 legislative elections, both the centre-right PDL and the Social Democrat Party (PSD) ${ }^{7}$ sought to strengthen their territorial presence in Europe and North America by actively identifying local party members and sympathisers. As commented by the representative of the Social Democrat and Liberal Union (USL), the success of the PDL in capturing the emigrant vote in the presidential referendum from 2007, made the social democrats and liberals realise the importance of this electoral group (interview, USL, December 2012). Illustratively, in the run-up to the 2012 elections, the People Party (PPDD), founded only in 2011, immediately launched what they refer to as a more "focused" transnational strategy citing more than 53 local branches in Spain and Italy where there is a high concentration of Romanian emigrant voters (interview PPDD, December 2012).

However, the Romanian parties have established a rather weak ideological linkage compared to the other parties in this category. The ratio of the emigrant related proposals is influenced by the fact that the Romanian electoral programmes are significantly shorter than their Spanish, French and Italian counterparts. Whereas the Alliance Just Romania (ARD) and PPDD do have a special section in their program dedicated to the emigrants, their policy proposals are few and relatively unspecified. The parties cite the recent history of Romanian migration and the necessity to better understand what claims and needs emigrants may have, before formulating more specific emigrant policies (interviews with ARD, February 2013 and USL, December 2012).

As these examples illustrate, the dynamic in Spain, France and Romania is for major parties to 'catch up' with each other in terms of both their number of branches abroad and the particular policy proposals directed at emigrant voters. The case of Italy differs as the PdL was relatively 'unpresent' abroad in terms of both local branches and a party level emigrant policy compared to the PD during the time period included in this research. 
Besides these major parties, only the Europe Ecology - The Greens (EELV) from France displayed a relatively strong transnational outreach. The Greens have had a relative lack of emigrant electoral support in past elections, but the party cites the possibility of winning seats in the National Assembly in the 2012 elections as an important incentive to include an independent section on emigrants in their main programme, create a party federation for emigrant voters and field candidates in nine of the 11 districts. Moreover, the party increased its transnational organisational resources through the merger with Europe Ecology whose extensive network of transnational contacts facilitated the mobilisation for the emigrant vote (interview, EELV, November 2012). This experience shows that a stronger transnational network related to social movements constitute a highly relevant resource for outreach to emigrant voters.

In the category of parties with an extensive transnational infrastructure but few policy proposals related to emigrants, we find parties which can spend resources on a transnational presence among emigrant voters but choose to campaign mainly on their national programme. In the case of the Five Star Movement (M5S) the motive appears to be a combination of the type of party with a stronger grass-root based organisation and the fact that this was the party's first national electoral campaign. In order to capture the emigrant vote, the party mobilised 21 local branches abroad (called 'meet ups') led by sympathisers among emigrants and presented 19 candidates for the Chamber of deputies and 12 for the Senate. To that end they used a growing network of M5S supporters residing abroad (interview with M5S, July 2013). In contrast to the M5S, the Front National (FN) has a longstanding trajectory in terms of the emigrant vote in presidential elections although its support has never come close to that of the two main parties of the UMP and PS or its success among the national electorate. The Front National claimed 23 branches abroad during its 2012 campaign and presented candidates in all districts. The M5S relates its lack of specific emigrant policy proposals to the fact that this was their first national election and the strong priority of the party to reform of Italian politics. The FN linked their candidates to the main programme of Marie le Pen, which made no reference to emigrant voters.

The category of parties with a limited transnational infrastructure but with many policy proposals for emigrants includes two smaller Spanish parties who have not invested in a transnational local network because of a lack of resources or a strong geographical concentration of their main group of emigrant supporters. Both the United Left (IU) and 
the Canarian Coalition (CC) have been reaching out to emigrants for decades and motivate their transnational campaign with a sense of affinity and responsibility towards the emigrant voters. Despite a decline in electoral support from emigrants, the IU continues to emphasise its commitment to represent the concerns of Spanish workers abroad. Yet, their resources only allow for maintaining their six branches abroad within the EU (Interview, IU, June 2012). The CC also motivates reaching out to emigrants with its historical and strong connections to emigrants originating from the Canary Islands. There is, moreover, an important electoral incentive as the CC have won more than 50 per cent of the emigrant vote in the 2003 and 2007 regional elections. Indeed, in the 2008 national elections the CC won a senator based on the marginal difference made up by the emigrant vote (Lugilde 2007). The CC electoral programme makes references to the Canarians abroad as an important part of the Canarian polity and argues that this sends an important message both abroad and at home. However, most of these emigrants live in Venezuela, which is why the CC has concentrated its local presence there. The CC exemplifies how electoral incentives in overlapping arenas between regional and national politics in the homeland shape party transnational strategies.

In the case of Italy, the Civic Choice, which ran for the first time in 2013 under the leadership of outgoing prime minister Mario Monti, motivates its transnational campaign with a perception that especially voters based in other EU countries would support this party. Their candidate for the European district had already served as a special emigrant representative for the PdL in 2008-2013 and had experience and local contacts facilitating the campaign. Moreover, the party reduced the cost of campaigning by going into coalition with the main emigrant led party, Maie, in the American districts. Finally, in the case of Romania, the Democratic Hungarian Party (UDMR) has a set of policies addressing ethnic Hungarians born in Romania who emigrated to Hungary, mostly related to party's mediating role in improving their status in the host country. However, the party does not report any infrastructure beyond the Romanian borders.

In the last category of the parties with a limited transnational infrastructure and few policy proposals for emigrants we find a range of parties from all four countries which have in common that they are small, have little prior support among emigrant voters in previous elections or do not support emigrant enfranchisement in the first place. For instance, at the time of this research, the Republican Left of Catalunya (ERC) representative explained that the high dispersion of Catalan origin emigrant voters 
combined with low rates of participation rendered them uninteresting for both them and the other main Catalan party, the Covergence and Union (Interview, ERC July 2012). Moreover, three of the parties in this category refer to a lack of enthusiasm for the emigrant enfranchisement combined with scarce resources as part of their decision to not campaign abroad. In the case of Spain, the regional party of the Galician Nationalist Bloc (BNG) is based in a context with high numbers of emigrant voters ( $>14$ per cent of the Galician electorate) which mainly support the PP and PSOE in regional and national elections. The BNG has repeatedly supported legislative proposals abolishing or reducing emigrant voting rights (Lugilde 2007). That said, the BNG mainly cites lack of resources as the main reason for not keeping up any official network of party branches abroad (Interview BNG, June 2012). The Left Front from France (FdG) and the Italian Left Ecology Freedom (SEL) are both coalitions of left-wing parties running under a new joint label for the elections in 2012 and 2013 respectively. The FdG fielded candidates in all 11 districts but offered limited resources in terms of joint emigrant related campaign programme and travel expenses. They made use of some of the infrastructure and networks of the French Communist Party but had no transnational infra-structure of their own yet (Interview FdG, February 2013). The SEL decided to field candidates under their own party label in the European district only and endorse the PD candidates in the rest of the world. Besides references to a lack of resources, SEL also emphasised that it sees the (lack of) immigrant voting rights as a more important issue than the vote and situation of non-resident Italians (Interview SEL, June 2013).

\section{Conclusions}

The enfranchisement of emigrants creates a transnational electoral field between homelands and citizens abroad. However, parties differ in the extent to which they seek to establish cross-border linkages with non-resident voters. In this paper we have suggested that transnational party outreach needs to be understood both in the context of general understandings of the effect of electoral institutions, political competition and party characteristics as well as insights on emigrant political behaviour and emigrant voting rights drawn from the literature on transnational migration. 
Overall, our analysis suggests that the basic logic of parties going transnational when the benefits outweigh the cost goes a long way towards explaining how parties navigate the transnational electoral field of emigrant voters, even though this field is characterised by complicated logistics as well as uncertainty, volatility and low turnout of the emigrant electorate. Consequently, the parties that are more present abroad in terms of their political programme and transnational infrastructure are the two main parties of each of the national party systems at the time of study. The main centre-right and left parties perceive a competitive advantage, as emigrant voters tend to converge on stronger parties as the most credible options to have political influence in the homeland. Recent studies have argued that the broader appeal as well as the mass organisations of these parties facilitate their linkage with partisan and independent voters (Dalton et al. 2011; Rohrschneider and Whitefield 2012). Similarly, the organisational resources of most of the larger main-stream parties in our analysis, such as developed and refined party structures and linkages with interest groups, seem particularly relevant for facilitating communication and linkage with the broad range of voters in different settings abroad.

In the category of parties who do not pursue the emigrant vote neither in terms of transnational presence or policy proposals we find a series of smaller and/or regional parties with limited campaign resources and low expectation of emigrant voter support. In the context of transnational campaigning, resources are, however, not just a matter of the size of the party organisation and its financial backup. The EELV or M5S are examples of how relatively smaller parties with a stronger linkage with transnational social movements can draw on these networks when establishing their transnational infrastructure of party branches.

Yet, there are also features of the transnational electoral scene which tempers the cost-benefit analysis based on electoral institutions, political competition and party resources. Political parties mention the past close results in legislative elections in Italy, presidential elections in Romania and regional elections in Spain as a driver to intensify or keep up their campaigns. Still, the uncertainly, volatility and low turnout of the emigrant vote renders it more difficult for parties to fine-tune their campaign strategy abroad. More detailed studies could compare the extent to which parties concentrate more on countries with higher numbers of emigrants or in districts with a particularly close result. In our broader analysis, a pattern appears where, given the uncertainty of emigrant voting preferences and turnout, parties seek to avoid being relatively invisible in terms of local 
contact with and policy messages to emigrant voters. A catch-up or visibility logic characterises the transnational behaviour of the larger and more resourceful political parties. The restrictions of emigrant voting rights in Spain before the 2011 elections do not appear to have influenced the transnational reach-out effort of parties indicating that once parties have their transnational campaign message and infra structure set up it is less costly to keep it running.

Moreover, the particular context of emigration matters for party transnational outreach. In the countries with a longer trajectory of emigration and external voting rights political parties have a stronger tendency to include emigrant concerns in their political programmes. In contrast, Romanian parties are still in the process of understanding emigrants as a permanent presence abroad. Their transnational party strategies are characterised by a rapidly expanding transnational presence but more limited attempts to concretely addressing emigrant concerns in party programmes.

The dynamic of overlapping electoral arenas in cases where emigrants vote in different types of homeland elections is noticeable in Romania and Spain. The close results in the Romanian presidential elections or Spanish regional elections encourage parties to compete for the emigrant vote in these type of elections with a spillover effect to campaigning abroad also in national legislative elections. Further studies could explore the dynamics of party outreach also in European or, in particular, local elections where dual or European citizens have voting rights both in their country of origin and residence hence providing more incentive for transnational collaboration among parties in both countries.

The notion of overlapping electoral arenas between homeland and emigrant electoral settings is, in this analysis, mainly relevant to cases of high rates of emigration to particular destination countries such as the case of the Canarian Coalition party. Otherwise, party awareness of a spillover effect from reaching out to emigrant voters were not among the salient motives expressed by parties in our cases. Broader comparative studies, including also cases beyond the EU and cases with stronger differences in emigrant transnational influence through economic and social remittances would allow us to better understand the logic of overlapping electoral arenas and spillover mechanisms. To that end, this paper suggests that the relevance of overlapping electoral arenas is not just a feature of particular situations of strong transnational ties between emigrants and their homeland, but can also be mediated by the type of electoral system institution in 
place. In particular, it is worth exploring further if this logic of spillover is more likely in cases where emigrant votes are counted in the same district (legislative elections without special representation and presidential elections) than in cases of special representation where parties compete for a particular number of seats among emigrant voters only.

Finally, general party endorsement of emigrant voting rights also plays into the motivation of especially smaller parties to pursue the emigrant vote although this does not follow any particular left-right logic. In some cases there is a strong fit between the overall party ideology and the perceived socio-economic profile of the emigrant voters as in the case of the Spanish United Left. Meanwhile, in other cases, the transnational campaign is tempered by a general position on the emigrant vote as less important than the voting rights of immigrants. A recent study has shown a negative relationship between party support for the granting of external voting rights and support for multiculturalism (ØstergaardNielsen et al. 2015). Further studies could investigate the extent to which party position on immigration influences the degree of transnational outreach of parties and the extent to which both endorsement and outreach are related back to expected or experienced electoral return among emigrant voters.

The increased mobility of voters combined with the expansion of cross border voting rights challenges parties to reconfigure their strategies of mobilisation. In this paper we have suggested a conceptual framework drawing on both insights from party behaviour in a domestic setting and the characteristics of emigrant voting rights and transnational electoral field. Such framework help explain both the dynamic of competition among the bigger parties as well as the transnational outreach of smaller parties with no expectation of any substantial electoral return. Further more in-depth studies can reveal the broader set of outreach activities in particular contexts, while broader studies can explore to what extent the findings from this paper are relevant for a different or broader set of cases. The case studies presented here demonstrate the extent to which political parties are capable of not just adapting to but also structuring the content and infrastructure of transnational democratic processes in the wake of the enfranchisement of emigrant voters. 


\section{References:}

Best, Robin E. (2010). 'Increasing Irrationality? The Equilibrium Relationship between Electoral and Legislative Party System Size, 1950-2005, Electoral Studies, 29:1, 105-116.

Boccagni, Paolo, Jean-Michel Lafleur and Peggy Levitt (2015). 'Transnational Politics as Cultural Circulation: Toward a Conceptual Understanding of Migrant Political Participation on the Move', Mobilities, 11:3, 1-20.

Burgess, Katrina (2018). 'States or Parties ? Emigrant Outreach and Transnational Engagement', International Political Science Review, DOI: 10.1177/0192512118758154.

Caramani, Daniele and Florian Grotz (2015). 'Beyond Citizenship and Residence? Exploring the Extension of Voting Rights in the Age of Globalization, Democratization, 22:5, 799-819.

Collard, Susan (2013). 'The Expatriate Vote in the French Presidential and Legislative Elections of 2012: A Case of Unintended Consequences', Parliamentary Affairs, 66:1, 213-233.

Collyer, Michael (2013). Emigration Nations: Policies and Ideologies of Emigrant Engagement, Basingstoke: Palgrave Macmillan.

Cox, Gary W. (1999). 'Electoral Rules and the Calculus of Mobilization', Legislative Studies Quarterly, 24:3, 387-419.

Cox, Gary W. (1997). Making Votes Count: Strategic Coordination in the World's Electoral Systems. New York: Cambridge University Press.

Dalton, Russell J., David M Farrell and Ian McAllister (2011). Political Parties and Democratic Linkage: How Parties Organize Democracy. Oxford: Oxford University Press.

Dietz, Thomas (2000). 'Similar But Different : The European Greens Compared to Other Transnational Party Federations in Europe', Party Politics, 6:2, 199-210.

Duverger, Maurice (1954). Political Parties: Their Organization and Activity in the Modern State. London: Methuen. 
Gamlen, Alan (2008). 'The Emigration State and the Modern Geopolitical Imagination, Political Geography, 27:8, 840-856.

Gibson, Rachel K. and Andrea Rommele (2009). 'Measuring the Professionalization of Political Campaigning', Party Politics, 15:3, 265-293.

Guinjoan, Marc (2014). Parties, elections and electoral contests. Surrey: Ashgate.

Karp, Jeffrey A., Susan A. Banducci and Shaun Bowler (2007). 'Getting Out the Vote: Party Mobilization in a Comparative Perspective', British Journal of Political Science, 38:1, 91-112.

Kriesi, Hanspeter, Laurent Bernhard, and Regula Hänggli (2009). 'The Politics of Campaigning - Dimensions of Strategic Action'. in B. Pfetsch and F. Marcinkowski (eds.) Politik in der Mediendemokratie., Viesbaden: Verlag für Sozialwissenschaften, 345-365.

Lafleur, Jean-Michel (2013). Transnational Politics and the State: The External Voting Rights of Diasporas. London:Routledge.

Lago, Ignacio and Ferran Martínez (2007). 'The Importance of Electoral Rules: Comparing the Number of Parties in Spain’s Lower and Upper Houses'. Electoral Studies, 26:2, 381-391.

Lago, Ignacio and José Ramon Montero (2009). 'Coordination between Electoral Arenas in Multilevel Countries', European Journal of Political Research, 48:2, 176-203.

Lugilde, Anxo (2007). O Voto Emigrante: Viaxe Pola Zona Escura da Democracia Española. Santiago de compustela: Editorial Galaxia.

Mahmoud, Toman Omar, Hillel Rapoport, Andreas Steinmayr, Christoph Trebesch (2013). 'The Effect of Labor Migration on the Diffusion of Democracy: Evidence from a Former Soviet Republic', CESifo Working Paper Series No. 4389, retrieved from https://papers.ssrn.com/sol3/papers.cfm?abstract_id=2327441.

Mair, Peter., Wolfgang C. Müller and Frits Plasser (2004). Political Parties and Electoral Change: Party Responses to Electoral Markets. London: SAGE.

Matsusaka, John G (1993). 'Election Closeness and Voter Turnout: Evidence from California Ballot Propositions, Public Choice, 76:4, 313-334.

Meseguer, Covadonga and Katrina Burgess ( 2014). 'International Migration and Home Country Politics', Studies in Comparative International Development, 49:1, 1-12. 
Norris, Pippa (2005). Political Parties and Democracy in Theoretical and Practical Perspectives. Washington: National Democratic Institute for International Affairs.

Østergaard-Nielsen, Eva (2016). 'Sending Country Policies', in Blanca GercésMascareñas nd Rheinus Penninx, Integration Processes and Policies in Europe. Contexts, Levels and Actors. Heidelberg: Springer, 147-165.

Østergaard-Nielsen, Eva (2003). Transnational Politics: Turks and Kurds in Germany. London/New York: Routledge.

Østergaard-Nielsen, Eva and Irina Ciornei (2017). 'Making the Absent Present: the Salience and Representation of Emigrants in Country of Origin Parliaments, Party Politics, DOI: 10.1177/1354068817697629

Østergaard-Nielsen, Eva, Irina Ciornei and Jean-Michel Lafleur (2015). 'Why do Parties Support External Citizenship. Paper presented at the Europeanist Conference, July 7-9.

Paarlberg, Michael A. (2017). Diaspora Outreach by Latin American Parties. Georgetown University.

Pappi, Franz and Nicole Seher (2009) 'Party Election Programmes, Signalling Policies and Salience of Specific Policy Domains: The German Parties from 1990 to 2005', German Politics, 18:3, 403-425.

Pfutze, Tobias (2014). 'Clientelism Versus Social Learning: The Electoral Effects of International Migration', International Studies Quarterly, 58:2, 295-307.

Ragazzi, Francesco (2014). A Comparative Analysis of Diaspora Policies, Political Geography, 41, 74-89.

Raymond, Christopher (2016). 'Explaining the multiparty systems of Western Europe prior to the adoption of proportional representation', Comparative European Politics, 14:3, 253-272.

Rohrschneider, Robert and Stephen Whitefield (2012). How Parties Represent Diverse Voters in Western and Eastern Europe. Oxford: Oxford University Press.

Tintori, Guido (2012). Il Voto degli aAltri. Rappresentanza e Scelte Elettorali degli Italiani all'Estero. Torino: Rosenberg and Sellier. 


\begin{tabular}{|c|c|c|c|c|c|c|c|c|c|}
\hline Country & Party name & Abbreviation & Election & $\begin{array}{l}\text { Ideological } \\
\text { linkage }\end{array}$ & $\begin{array}{l}\text { Number of } \\
\text { emigrant } \\
\text { related } \\
\text { proposals/ } \\
\text { themes }\end{array}$ & \begin{tabular}{|l|} 
Transnational \\
infrastructure
\end{tabular} & $\begin{array}{l}\text { Emigrant } \\
\text { electoral } \\
\text { support last } \\
\text { election in } \\
\%\end{array}$ & $\begin{array}{l}\text { Closeness } \\
\text { last election } \\
\text { in \% }\end{array}$ & $\begin{array}{l}\text { Number of } \\
\text { candidates } \\
\text { presented in } \\
\text { external districts }\end{array}$ \\
\hline \multirow[t]{8}{*}{ Spain } & Popular Party/Partido Popular & PP & 2011 & 1,25 & 7 & 44 & 28,05 & 29,42 & n.a \\
\hline & $\begin{array}{l}\text { Spanish Socialist Workers } \\
\text { Party/Partido Socialista Obrero } \\
\text { Español }\end{array}$ & PSOE & 2011 & 1,13 & 14 & 37 & 57,47 & 29,42 & n.a \\
\hline & United Left/Izquierda Unida & IU & 2011 & 2,99 & 31 & 6 & 1,79 & 29,42 & n.a \\
\hline & $\begin{array}{l}\text { Canarian Coalition /Coalicion } \\
\text { Canarias }\end{array}$ & CC & 2011 & 0,66 & 3 & 2 & 2,74 & 29,42 & n.a \\
\hline & $\begin{array}{l}\text { Galician Nationalist Bloc/Bloque } \\
\text { Nacionalista Gallego }\end{array}$ & BNG & 2011 & 0,00 & 0 & 5 & 0,82 & 29,42 & n.a \\
\hline & $\begin{array}{l}\text { Convergence and } \\
\text { Union/Convergencia i Unio }\end{array}$ & $\mathrm{CiU}$ & 2011 & 0,00 & 0 & 2 & 1,32 & 29,42 & n.a \\
\hline & $\begin{array}{l}\text { Union, Progress and } \\
\text { Democracy/Unión Progreso y } \\
\text { Democracia }\end{array}$ & UpyD & 2011 & 0,00 & 0 & 2 & 0,66 & 29,42 & n.a \\
\hline & $\begin{array}{l}\text { Republican Left of } \\
\text { Catalunya/Esquerra Republicana } \\
\text { de Catalunya }\end{array}$ & ERC & 2011 & 0,03 & 1 & 0 & 0,51 & 29,42 & n.a \\
\hline \multirow[t]{5}{*}{ France } & $\begin{array}{l}\text { Union for a Popular Movement } \\
\text { /Union pour un mouvement } \\
\text { populaire }\end{array}$ & UMP & 2012 & 13,63 & 25 & 100 & 38,49 & 8,57 & NA: $11 / 11$ \\
\hline & Socialist Party/ Parti Socialiste & PS & 2012 & 19,88 & 28 & 60 & 29,92 & 8.57 & NA: $10 / 11$ \\
\hline & $\begin{array}{l}\text { Europe Ecology - The } \\
\text { Greens/Europe-Écologie Les } \\
\text { Verts }\end{array}$ & EELV & 2012 & 0,65 & 13 & 11 & 1,98 & 8.57 & NA:9/11 \\
\hline & Left Front/Front de Gauche & FdG & 2012 & 0,00 & 0 & 0 & 0,56 (PCF) & 8.57 & NA:11/11 \\
\hline & National Front/Front National & FN & 2012 & 0,00 & 0 & 23 & 3,27 & 8.57 & NA:11/11 \\
\hline
\end{tabular}




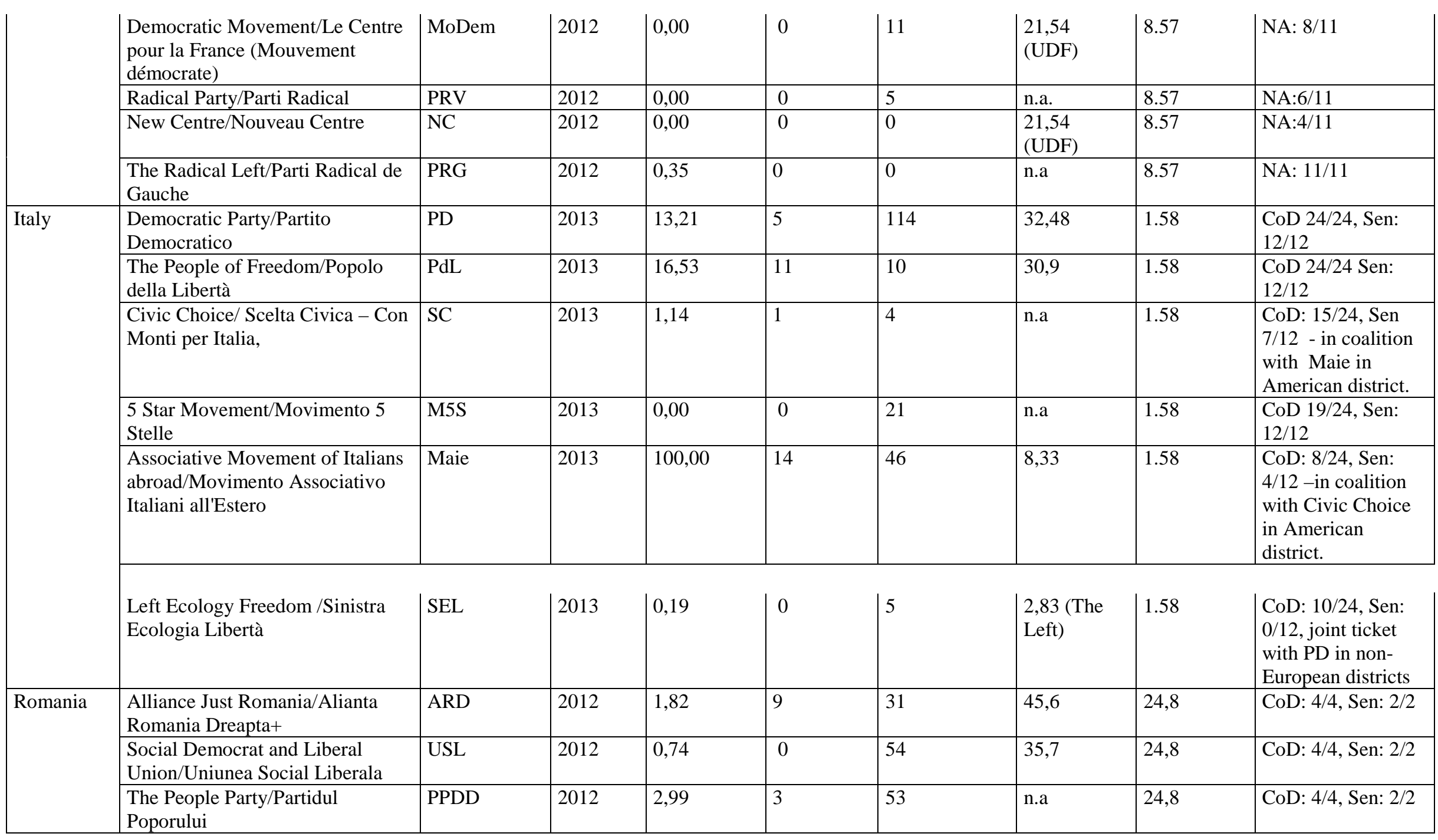




\begin{tabular}{|l|l|l|l|l|l|l|l|l|}
$\begin{array}{l}\text { Hungarian Democratic } \\
\text { Union/Uniunea Democrata a } \\
\text { Maghiarilor din Romania }\end{array}$ & UDMR & 2012 & 0,93 & 0 & 24,8 \\
\hline
\end{tabular}

Notes: Ideological linkage: percentage of emigration related words over total number of words in the electoral programme. Transnational infrastructure: number of external branches.

Year of last election: France 2007 presidential elections, $1^{\text {st }}$ round; Italy 2008 legislative elections for CdD; Spain 2008 legislative elections; Romania 2008 legislative

elections; NA: National Assembly; CoD: Chamber of Deputies; Sen: Senate; Closeness of the result: the difference between results among all emigrant voters of the two most voted parties. Some smaller parties taking less than $3 \%$ of the vote in Italy, France and Spain have not been included.

Coalitions: USL is a temporary alliance of the National Liberal Party (PNL), the Social Democrat Party (PSD) and the Conservative Party (PC). ARD is a temporary alliance of the Democrat Liberal Party (PDL), Christian Democratic Peasants' Party (PNTCD) and Civic Force (FC). The ideological linkage, transnational infrastructure scores and electoral support are the sum of the corresponding number for each party. For the other coalitions of Civil Choice/Maie and PD/SEL in the case of Italy the numbers are reported per party as there were only coalitions in some districts. In the case of France, some branches appear to overlap with party presence in the Outre Mer districts which also have special representation.

Sources transnational infrastructure: Own elaboration from interviews and party websites accessed in the period 2011-2013. In the case of the UMP, the information was only collected/verified during 2014/5 and the number for the 2012 campaign could be slightly lower. In the case of the CiU the number is an estimate based on interview with a coalition party. The number for the Upyd is taken from an interview in an emigrant online journal in 2009.

Sources ideological linkage: Electoral programmes downloaded from party websites and general repositories like the Comparative Manifesto Project. In a few cases the parties post particular programmes for emigrants but otherwise the word count is generally taken from within the general programme. Other sources: Electoral statistics from: https://www.interieur.gouv.fr/Elections/Les-resultats; http://elezionistorico.interno.it/; http://www.roaep.ro/istoric/; http://www.infoelectoral.mir.es/infoelectoral/min/ 
${ }^{1}$ Globalcit database on electoral rights, http://globalcit.eu/, last accessed 15/1 2018.

${ }^{2}$ Conseil Economique, Social et Environnemental 2009. Les français établis hors de France : leurs attentes, leurs besoins. Journal officiel de la république française. Avis et rapports du conseil économique, social et environnemental, $\quad \mathrm{nr}$. 2, see $\quad$ http://www.ladocumentationfrancaise.fr/rapportspublics/094000062/index.shtml, last accessed 20/08/2018

${ }^{3}$ Electoral results for Italy, see http://elezionistorico.interno.it. Electoral results for Romania, see http://alegeri.roaep.ro.

${ }^{4}$ Heraldo, 14.03.2008, 'El voto emigrante amplía la ventaja del PSOE en un millón de votos.'

5 El Dia, 07.03.2009, “El PSE consigue su escaño 25 con el voto de los residentes en el extranjero”; El Pais, 17.03.2008, "Melchior, el senador emigrante”

${ }^{6}$ Asturias Exterior, 30.03.2012, “El voto emigrante decide en Asturias”, El Mundo, 26.06.2005 “El decisivo voto de los emigrantes”.

${ }^{7}$ In the 2012 elections, the PDL was part of the Alliance Just Romania (ARD) and the Social Democrat Party (PSD) was part of the Social Liberal Union (USL). 